\title{
Model Tatalaksana Komprehensif Tuberculosis Multidrug-Resistant (TB-MDR) Melalui Pendekatan Provider Pelayanan Kesehatan
}

\author{
Okky Haidar Yahya Irawansa ${ }^{1}$, Yudha Bhaskoro ${ }^{2}$, Ahmad Rizki Maulana ${ }^{3}$, \\ Febri Endra Budi Setyawan ${ }^{*}$ \\ 1,2,3 Pendidikan Dokter, Universitas Muhammadiyah Malang \\ ${ }^{4}$ Departemen Kedokteran Keluarga, Universitas Muhammadiyah Malang
}

\begin{abstract}
ABSTRAK
Tuberkulosis merupakan penyakit yang sangat menular dan membutuhkan pengobatan dalam jangka waktu yang panjang dan jumlah obat yang banyak. Hal ini dapat mempengaruhi tingginya risiko terjadinya Tuberculosis Multidrug-Resistant (TB-MDR). Pendekatan pelayanan kesehatan dalam memberikan tatalaksana secara komprehensif meliputi promotif, preventif, kuratif, rehabilitatif sangat diperlukan untuk menanggulangi kasus tersebut. Artikel ini bertujuan untuk menentukan intervensi yang dapat dilakukan oleh pelayanan kesehatan dalam mencegah terjadinya Tuberkulosis Multidrug Resistant (TB-MDR). Metode yang digunakan adalah penelusuran pustaka melalui jurnal nasional hingga internasional yang meneliti mengenai intervensi yang dapat dilakukan oleh pelayanan kesehatan dalam mencegah terjadinya TB-MDR. Artikel atau sumber data yang telah diperoleh akan dibandingkan satu dengan yang lainnya sehingga dapat ditemukan faktor yang paling berpengaruh terhadap terjadinya TB-MDR. Hasil penelusuran pustaka menunjukkan bahwa tenaga kesehatan khususnya dokter memiliki peran penting dalam penatalaksanaan kasus TB-MDR. Penatalaksanaan TB-MDR secara komprehensif dilakukan melalui program promotif, preventif, kuratif dan rehabilitatif melalui pendekatan provider pelayanan kesehatan. Kegiatan edukasi mengenai penyakit TB, TB-MDR, ataupun kemungkinan terjadinya resistensi obat penting dilakukan untuk mencegah terjadinya kasus TB-MDR yang baru. Penanganan secara kuratif dilakukan untuk meningkatkan kesehatan mental dan sosial. Selanjutnya upaya rehabilitatif dilakukan sebagai sarana untuk meningkatkan pemulihan status kesehatan penderita TB-MDR. Kesimpulan penelusuran pustaka adalah melalui pendekatan provider pelayanan kesehatan dengan peningkatan fasilitas yang tersedia dapat melakukan tatalaksana promotif preventif kuratif rehabilitatif untuk menekan kejadian TB-MDR.
\end{abstract}

Kata kunci: tatalaksana komprehensif; pendekatan provider pelayanan kesehatan, tuberculosis; TB-MDR.

\begin{abstract}
Introduction: Tuberculosis is a highly contagious disease and requires long-term treatment and large amounts of medication. This can affect the high risk of Multidrug-Resistant Tuberculosis (MDR-TB). A health service approach in providing comprehensive management including promotive, preventive, curative, and rehabilitative is very necessary to overcome these cases. Aim of study: This article aims to determine interventions that can be carried out by health services in preventing the occurrence of multidrug-resistant tuberculosis (MDR-TB). Method: The method used is a literature review through national to international journals that examine the interventions that can be carried out by health services in preventing MDR-TB. The articles or data sources that have been obtained will be compared with one another so that the factors that most influence the occurrence of MDR-TB can be found. Results and Discussion: The literature search results show that health workers, especially doctors, have an important role in managing MDR-TB cases. Management of MDR-TB in a comprehensive manner is carried out through promotive, preventive, curative, and rehabilitative programs through a health service provider approach. Educational activities regarding TB, MDR-TB, or the possibility of drug resistance are important to do to prevent new cases of MDR-TB. Curative treatment is carried out to improve mental and social health. Furthermore, rehabilitative efforts are carried out as a means to improve health status recovery for MDR-TB sufferers. Conclusion: Health service providers can improve facilities, they can carry out promotive, curative rehabilitative management to reduce the incidence of MDR$T B$.
\end{abstract}

Keywords: comprehensive treatment; health service approach; tuberculosis; multidrug-resistant tuberculosis

*Korespondensi penulis:

Nama : Febri Endra Budi Setyawan

Instansi : Fakultas Kedokteran Universitas Muhammadiyah Malang

Alamat : Jl. Bendungan Sutami 188A Malang, Jawa Timur, Telp.: +62-341-552443/+62-341-582260

Email :febri@umm.ac.id 


\section{Pendahuluan}

Penyakit tuberkulosis menjadi masalah kesehatan dengan morbiditas dan mortalitas yang tinggi. Tuberkulosis merupakan masalah kesehatan dunia terutama pada negara berkembang seperti Indonesia. ${ }^{1}$ Pada tahun 2016, WHO mendapatkan sekitar 10,4 juta orang telah terjangkit TB dan Indonesia termasuk dalam salah satu dari 5 negara penyumbang terbesar. Penderita TB yang mengalami resisten obat di Indonesia diperkirakan sekitar 6100 kasus yang terjadi setiap tahunnya. ${ }^{2}$ Menurut data dari Direktorat Jenderal Pencegahan dan Pengendalian Penyakit (P2P) Kemenkes RI 2018, Provinsi Jawa Timur mencatatkan sebanyak 48.323 kasus TB dan termasuk daerah tertinggi kedua di Indonesia dibawah Jawa Barat. ${ }^{3}$ Data mengenai kejadian Tuberkulosis resisten obat di Jawa timur sekitar 881 kasus yang mengalami Tuberculosis Multidrug-Resistant (TB-MDR) dengan 59\% mendapatkan pengobatan dan $41 \%$ tidak mendapatkan penanganan apapun. ${ }^{4}$ Pada tahun 2017, angka kejadian kasus TB di Kabupaten Jember cukup tinggi. Menurut data dari Kominfo Jatim 2016, kasus TB di daerah Jember mencapai 3.128 dan tertinggi kedua setelah Surabaya. Hal yang lebih membuat khawatir adalah berdasarkan data Dinas Kesehatan Kabupaten Jember terdapat peningkatan kasus TB resisten obat dari 6 orang pada tahun 2013 menjadi 225 orang pada tahun $2017 .^{5}$

Tuberkulosis adalah penyakit menular pada manusia yang disebabkan oleh Mycobacterium tuberculosis (MTB). ${ }^{6}$ MTB tersebut merupakan bakteri basil tahan asam yang menyerang paru maupun jaringan lainnya (ekstrapulmoner). ${ }^{7}$ Pada orang yang terinfeksi, MTB dapat menyebar melalui udara yakni seperti batuk, bersin, dan droplet air ludah yang kemudian terhirup oleh orang disekitarnya. ${ }^{6}$ Menurut Kemenkes RI pada tahun 2020, TB resisten obat adalah penyakit menular yang disebabkan oleh Mycobacterium tuberculosis yang telah mengalami kekebalan obat anti tuberkulosis. ${ }^{8}$ Multidrug-resistant tuberculosis adalah pasien terinfeksi MTB yang kebal terhadap obat anti tuberkulosis isoniazid dan rifampisin. ${ }^{9}$ Pengobatan TB yang panjang, jumlah obat yang banyak dan efek samping obat yang bervariasi mengakibatkan terjadinya resiko putus obat TB. ${ }^{10}$ Maka dari itu, pasien dengan riwayat $\mathrm{TB}$ memiliki resiko yang lebih besar untuk mengalami TB-MDR. ${ }^{11}$ TB resistensi obat juga dapat terjadi karena pemberian obat anti tuberkulosis yang tidak tepat yaitu kesalahan dosis, durasi dan kualitas obat dari tenaga kesehatan, atau juga ketersediaan obat yang kurang memadai. ${ }^{12}$

Pada umumnya manajemen kesehatan yang selama ini dilakukan hanya ditujukan untuk menangani keluhan pasien atau biasa disebut kuratif. Saat ini layanan pengendalian TB terfokus terhadap penyembuhan terhadap mikrobiologisnya, sedangkan pasien TB juga mengalami penderitaan secara mental dan sosial. ${ }^{13}$ Program kuratif sendiri dirasa memakan biaya cukup tinggi sehingga dilakukannya manajemen kesehatan dengan tatalaksana komprehensif diantaranya adalah promotif, preventif, kuratif, dan rehabilitatif dirasa lebih efektif. ${ }^{14}$ Promosi kesehatan adalah kegiatan penyuluhan dengan tujuan memastikan perilaku dan kesejahteraan hidup manusia. Preventif bertujuan memberantas dan mencegah penyakit. Kuratif adalah proses untuk mengurangi keluhan pasien, dan rehabilitatif adalah proses mengembalikan tubuh seperti normal kembali. ${ }^{15}$ Dalam mensukseskan program tersebut perlu adanya hubungan antara fasilitas yang tersedia, pengetahuan dan keterampilan sumber daya manusia, serta program yang akan dijalankan.

\section{Metode}

Studi ini dilakukan sebagai tinjauan artikel yang menganalisis pengaruh pelayanan kesehatan terhadap kejadian TB-MDR. Metode penelusuran artikel dilakukan dengan dua tahap. Pertama, peneliti melakukan penelusuran pustaka untuk mengetahui teori mengenai tatalaksana secara komprehensif. Melalui penelusuran dari database Google Scholar dengan memasukkan kata kunci berupa "promotive preventive curative rehabilitative tuberculosis" maka ditemukan sebanyak 17.000 artikel. Kemudian pencarian 
dirancang untuk mengidentifikasi artikel mengenai TB yang diterbitkan dari 5 tahun terakhir dan ditemukan sebanyak 4.700 artikel. Penambahan kata kunci "comprehensive treatment" ditambahkan untuk mengerucutkan penelusuran dan ditemukan sebanyak 1.400 artikel. Pengurutan diatur berdasarkan relevansi dengan kata kunci dan dilihat dari isi abstrak yang sesuai sehingga diperoleh 6 artikel sebagai sumber untuk teori tatalaksana TB secara komprehensif.

Kedua, peneliti berencana untuk mencari data penelitian mengenai pengaruh pelayanan kesehatan terhadap kejadian TB-MDR dalam rentang waktu 5 tahun terakhir dilakukan dengan memasukkan kata kunci pada PubMed yaitu health service OR health service AND Multidrug-resistant tuberculosis OR Multidrugresistant tuberculosis dan didapatkan sebanyak 239 artikel. Setelah itu proses penelusuran artikel diarahkan pada topik yang berhubungan dengan kinerja tenaga kesehatan, program, dan juga fasilitas yang menunjang dari pemeriksaan TB. Penelusuran melalui database Google Scholar juga dilakukan dengan memasukkan kata kunci berupa "Pelayanan kesehatan", "health service", "TB-MDR", "multidrug-resistant tuberculosis", "Healthcare", "health worker", "Treatment tuberculosis", "diagnose tuberculosis". Hasil penelusuran selanjutnya didapatkan sejumlah 25 artikel dan ditambahkan keterbaruan data dari Kemenkes RI untuk bahan artikel. Total jumlah pustaka yang selanjutnya dijadikan sebagai bahan kajian yaitu sebanyak 34 artikel.

\section{Hasil dan Pembahasan}

Tenaga kesehatan khususnya dokter berperan penting dalam menurunkan kejadian TB-MDR. Pemberian edukasi mengenai penyakit TB, TB-MDR, ataupun kemungkinan terjadinya resistensi obat merupakan hal yang mendasar dalam kesuksesan penanganan TB. ${ }^{7}$ Penelitian yang dilakukan oleh De Vries et al. (2017) memaparkan bahwasanya pertumbuhan TB-MDR yang sangat tinggi terjadi karena penanganan yang tidak sesuai dengan standar pengobatan. ${ }^{16}$ Hal ini selaras dengan penelitian yang dilakukan Alotaibi et al. (2019) menunjukan hanya $25 \%$ tenaga kesehatan yang mengikuti seminar atau pelatihan mengenai tuberkulosis dalam 12 bulan ini, sehingga pengetahuan mengenai tuberkulosis dari tenaga kesehatan dirasa kurang. ${ }^{17}$ Secara ideal untuk melakukan tatalaksana secara komprehensif maka harus ada kerjasama antara tenaga medis, keperawatan, dan kefarmasian. Penelitian yang dilakukan Ayu (2019) di puskesmas Medan menunjukkan bahwa kekurangan dari pelayanan yang ada adalah kurangnya komunikasi efektif antara perawat dan pasien terutama dalam memberikan informasi mengenai efek samping, sedangkan untuk kefarmasian diharapkan tidak ada keterlambatan dalam distribusi obat. ${ }^{2}$

Di sisi lain, hal ini tidak selaras dengan penelitian yang dilakukan Muhammad et al. (2019) di Wilayah Kerja Puskesmas Pangkajene Kabupaten Sidenreng Rappang yang menunjukkan bahwasannya faktor keaktifan petugas tidak berbanding lurus dengan kejadian TB-MDR. ${ }^{18}$ Berdasarkan data dari penelitian tersebut tercatat $77,4 \%$ petugas kesehatan cukup aktif dibanding petugas yang kurang aktif. Penelitian Devi et al. (2019) yang dilakukan di Kota Semarang juga memaparkan bahwasanya pada wilayah kerja tersebut peran atau dukungan dari petugas kesehatan sudah cukup baik dengan persentase $85,7 \%$ dibanding petugas yang kurang aktif. ${ }^{19}$ Penelitian mengenai pengaruh kualitas pelayanan terhadap TB-MDR yang dilakukan di Jember oleh Trisno et al. (2019) yang membahas tangible, reliability, responsiveness, empathy, assurance, dan mutu pelayanan kesehatan menunjukkan frekuensi terbanyak jawaban responden adalah bagus. ${ }^{4}$

Penelitian oleh Janan et al. (2019) di Brebes menunjukkan data responden yang telah mendapatkan pengobatan sesuai dosis adalah $78,3 \%$ dibanding responden yang tidak mendapatkan pengobatan sesuai dosis. ${ }^{20}$ Penelitian Devi et al. (2019) yang dilaksanakan di Kota Semarang juga selaras dimana data mengenai penyuluhan informasi mengenai TB MDR menunjukkan sudah cukup baik. ${ }^{19}$ Menurut Vries et al. (2017) dalam penelitiannya juga 
memaparkan bahwa sistem kesehatan sudah diakui sangat baik, tetapi kejadian TB-MDR masih cukup tinggi dikarenakan kegagalan atau keberhasilan sistem kesehatan dalam menurunkan kejadian TB MDR dipengaruhi oleh beberapa faktor lain seperti sosio ekonomik, kesabaran pasien, perilaku, dan sikap terhadap pengobatan. ${ }^{16}$

Program dapat terlaksana dengan baik jika ditunjang dengan fasilitas yang memadai. Fasilitas seperti alat uji cepat molekuler, ruang dahak, keberadaan poliklinik rawat jalan dan rawat inap TB-MDR yang lokasinya dipisahkan dari area layanan lain, merupakan bentuk komitmen rumah sakit dalam memberikan pelayanan TB-MDR yang sesuai dengan regulasi. ${ }^{21}$ Pada penelitian di Jember oleh Trisno et al. (2019) didapatkan hasil yang cukup baik untuk fasilitas berupa ruangan TB, ruang isolasi, tersedianya lab, dan juga penyimpanan sputum. ${ }^{4}$ Perencanaan logistik yang baik juga merupakan faktor penting dalam keberhasilan pengobatan seperti persiapan atau perencanaan sumber daya yang memadai termasuk energi, biaya atau pendanaan, sarana prasarana, dan juga ketersediaan logistik dalam suatu kurun waktu tertentu. ${ }^{21,22}$ Pada penelitian Purwaningsih et al. (2018) yang meneliti tentang strategi pembiayaan TB di Samarinda yang belum efektif dan efisien membuat kasus TB meningkat secara signifikan. ${ }^{23}$ Pada beberapa negara seperti Prancis, Portugal, Mexico, dan Belgia memiliki program yang berbeda untuk menangani kasus TB seperti menggratiskan biaya penangan Tuberkulosis dengan menggunakan dana pajak, sumbangan pemerintah yang dilaksanakan berbasis hukum yang berlaku disetiap negara. ${ }^{24}$

Hubungan antara peran tenaga kesehatan, program, dan sarana prasarana memang tidak dapat dipisahkan. Kurangnya suatu pengetahuan $\mathrm{TB}$ di antara petugas kesehatan menyebabkan perawatan di bawah standar, pemanfaatan sarana prasarana menjadi tidak efisien, dan kualitas informasi yang diberikan ke masyarakat menjadi berkurang yang kemudian menjadikan semakin tingginya resiko penularan TB dan resistensi obat TB. ${ }^{25}$
Berhubungan dengan hal tersebut, Penelitian oleh Yani et al. (2020) dalam pembahasannya menyatakan bahwa salah satu penyebab terjadinya TB MDR adalah pengetahuan pasien. ${ }^{26}$ Faktor pengetahuan kepatuhan minum obat ada kemungkinan dapat diintervensi dengan program penyuluhan dimana dalam penelitian ini dihasilkan perbedaan peningkatan pengetahuan masyarakat dari sebelum adanya penyuluhan dan setelah penyuluhan diberikan.

Penelitian diatas belum menunjukkan pelayanan kesehatan secara komprehensif, dimana sebagian besar masih mengabaikan pencegahan penularan tuberkulosis sehingga dengan melakukan pendekatan provider pelayanan kesehatan maka fasilitas yang tersedia kemungkinan dapat digunakan secara maksimal, kemudian program promotif, preventif, kuratif, dan rehabilitatif dapat berjalan dengan benar dan tepat. $^{27}$

Program pengobatan yang baik, tetapi tidak didukung dengan lingkungan yang memadai maka transmisi dan perkembangan bakteri kemungkinan akan tetap tinggi. Menurut penelitian dari Nathavitharana et al. (2019) menunjukkan bahwa salah satu hal yang mempengaruhi terjadinya transmisi adalah terbatasnya ventilasi. ${ }^{28}$ Kegiatan promotif dan preventif yang dapat dilakukan oleh tenaga kesehatan adalah memberikan penyuluhan untuk selalu membuka jendela. Penelitian lain oleh Sayidah et al. (2018) mengungkapkan bahwa kepadatan hunian juga berpengaruh signifikan terhadap transmisi TB dan TB MDR. Setidaknya hal yang dapat diintervensi adalah penggunaan alat makan, alat mandi, pakaian harus dipisah dengan tujuan meminimalisasi transmisi TB MDR. ${ }^{29}$ Program promotif preventif juga dapat dilakukan dengan melibatkan tokoh masyarakat seperti organisasi masyarakat, penceramah agama, dan para pemimpin desa yang lebih dekat dan lebih dipercaya oleh masyarakat. ${ }^{30}$

Program kuratif tuberkulosis sudah terprogram secara nasional. Standar rejimen pengobatan tuberkulosis didunia juga dianggap sudah efektif. ${ }^{31}$ Meskipun demikian, peran tenaga kesehatan juga penting terhadap kesuksesan 
pengobatan. Kuratif secara komprehensif bukan hanya menyembuhkan dari penyakit tetapi pasien juga harus sehat mental dan sosial. ${ }^{13}$ Kesehatan mental dapat terganggu pada pasien TB karena pengobatan yang lama dan efek samping dari OAT. ${ }^{32}$ Menurut penelitian Muhammad et al. (2019) mengungkapkan bahwa terdapat hubungan antara keluarga dengan keteraturan minum obat. $^{18}$ Peran tenaga kesehatan diharapkan dapat memberikan penyuluhan kepada keluarga atau orang terdekat pasien tentang tata cara minum obat yang benar hingga tuntas, efek samping minum obat, meminta untuk selalu mengawasi pasien agar benar-benar menelan obat serta selalu memberikan dukungan kepada pasien. ${ }^{33}$ Selain itu, emotional support yaitu kasih sayang, kepedulian, dan kepercayaan dari keluarga akan meningkatkan kepercayaan diri pasien sehingga kesuksesan berobat akan tinggi. ${ }^{34}$

\section{Kesimpulan}

Melalui pendekatan provider pelayanan kesehatan dengan fasilitas yang tersedia, tatalaksana promotif preventif kuratif rehabilitatif dapat ditingkatkan untuk menekan kejadian TB-MDR. Upaya promotif dan preventif yang dapat dilakukan adalah dengan memberikan penyuluhan berupa ventilasi dan kepadatan hunian, serta kuratif dan rehabilitatif berupa penyuluhan kepada keluarga atau orang terdekat pasien untuk menjadi pengawas menelan obat dan memberikan emotional support supaya kepercayaan diri dari pasien dapat tumbuh dan kesuksesan pengobatan kemungkinan akan dicapai.

\section{Ucapan Terima Kasih}

Terima kasih kepada tim monitoring dan evaluasi dari Universitas Muhammadiyah Malang yang memberikan kritik dan saran kepada kami dalam menuliskan artikel ini, terimakasih kepada dosen pembimbing kami Dr. dr. Febri Endra Budi Setiyawan, M. Kes FISPH FISCM yang telah membimbing kami dari awal hingga akhir dalam pembuatan artikel ini.

\section{Referensi}

1. Yuliawati Y, Rahmi H, Yantari W, Yulion R. Hubungan Pengetahuan Penderita TB Paru, Pelayanan Kesehatan dan Pengawas Menelan Obat terhadap Tingkat Kepatuhan Pasien. J Chem Inf Model. [Internet]. 2018 Jun [cited 2020 Aug 10];53(9):1689-99. Available from: https://doi.org/10.30644/rik.v7i1.123.

2. Ayu MS. Analisis Pelayanan Terapeutik Pada Pasien Tuberkulosis Resisten Obat Di Kota Medan. J Jumantik [Internet]. 2019 Nov [cited 2020 Aug 11];4(2):199-212. Available from:

http://dx.doi.org/10.30829/jumantik.v4i2.56 18.

3. Kementrian Kesehatan Republik Indonesia. Data dan Informasi: Profil Kesehatan Indonesia 2017 [Internet]. 2018 Mar [cited 2020 Aug 11]. Available from: https://www.pusdatin.kemkes.go.id/resource s/download/pusdatin/profil-kesehatanindonesia/Data-dan-Informasi_ProfilKesehatan-Indonesia-2017.pdf.

4. Trisno Z, Ma'rufi I, Novi AC. The Health Centres Service Quality Effects on Multi Drugs Resistant Tuberculosis (MDR TB) Patients' Medication Adherence In Jember. World Journal of Advance Healthcare Research [Internet]. 2019 Jul [cited 2020 Aug 11];3(4):121-132. Available from: https://www.wjahr.com/admin/assets/article _issue/14062019/1564137788.pdf.

5. Dinas Kesehatan Kabupaten Jember. Dukungan Daerah Dalam Program Percepatan Eliminasi TB Kabupaten Jember [Internet]. 2018 Mar [cited 2020 Aug 11]. Available from: https://www.kemkes.go.id/resources/downlo ad/info-

terkini/materi\%20pra\%20rakerkesnas $\% 2020$ 18/04_\%20Paparan\%20Kadinkes\%20Kab\% 20Jember.pdf.

6. Bañuls A-L, Sanou A, Van Anh NT, Godreuil S. Mycobacterium tuberculosis: Ecology and evolution of a human bacterium. J Med Microbiol. 2015 Jan [cited 2020 Aug 11];64(11):1261-9. Available from: https://doi.org/10.1099/jmm.0.000171.

7. Syahrezki M. Faktor risiko tuberkulosis multidrug resistant (TB-MDR). J Agromedicine [Internet]. 2015 Nov [cited 2020 Aug 11];2(4):403-18. Available from: http://juke.kedokteran.unila.ac.id/index.php/ 
agro/article/view/1227/pdf

8. Kementrian Kesehatan Republik Indonesia. Manajemen Terpadu Pengendalian TB Resistan Obat (MTPTRO) [Internet]. 2020 [cited 2020 Aug 11]. Available from: https://tbindonesia.or.id/informasi/teknis/tb$\mathrm{mdr} /$.

9. Seung KJ, Keshavjee S, Rich ML. MultidrugResistant Tuberculosis and Extensively Drug-Resistant Tuberculosis. Cold Spring Harb Perspect Med. [Internet]. 2015 Apr [cited 2020 Aug 11];5(9):a017863. Available from:

https://doi.org/10.1101/cshperspect.a017863

10. Yuni IDAMA. Hubungan Fase Pengobatan TB dan Pengetahuan Tentang TB-MDR dengan Kepatuhan Pengobatan Pasien TB (Studi di Puskesmas Perak Timur). J Berk Epidemiol. [Internet]. 2017 Jan [cited 2020 Aug 11];4(3):301-312. Available from: https://doi.org/10.20473/jbe.v4i3.

11. Nurdin N. Analisis faktor-faktor Risiko Individu terhadap Tuberculosis Multidrug Resistant (TB MDR) di Provinsi Sumatera Selatan. J Kesehat Komunitas [Internet]. 2020 Apr [cited 2020 Aug 11];6:63-7. Available from: https://doi.org/10.25311/keskom.Vol6.Iss1.3 85.

12. Izudi J, Tamwesigire IK, Bajunirwe F. Surveillance for multi-drug and rifampicin resistant tuberculosis and treatment outcomes among previously treated persons with tuberculosis in the era of GeneXpert in rural eastern Uganda. J Clin Tuberc Other Mycobact Dis [Internet]. 2020 Feb [cited 2020 Aug 11];19:100153. Available from: https://doi.org/10.1016/j.jctube.2020.100153

13. Aggarwal AN. Quality of life with tuberculosis. J Clin Tuberc Other Mycobact Dis [Internet]. 2019 Dec [cited 2020 Aug 11];17:100121. Available from: https://doi.org/10.1016/j.jctube.2019.100121

14. Migliori GB, Tiberi S, Zumla A, Petersen E, Chakaya JM, Wejse C, et al. MDR/XDR-TB management of patients and contacts: Challenges facing the new decade. The 2020 clinical update by the Global Tuberculosis Network. Int J Infect Dis. [Internet]. 2020 Mar [cited 2020 Aug 11];92:S15-25. Available from: https://doi.org/10.1016/j.ijid.2020.01.042.

15. Wendimagegn NF, Bezuidenhout MC. Integrating promotive, preventive, and curative health care services at hospitals and health centers in Addis Ababa, Ethiopia. J Multidiscip Healthc. [Internet]. 2019 Apr [cited 2020 Aug 11];12:243-55. Available from:// https://doi.org/10.2147/JMDH.S193370.

16. De Vries G, Tsolova S, Anderson LF, Gebhard AC, Heldal E, Hollo V, et al. Health system factors influencing management of multidrug-resistant tuberculosis in four European Union countries - learning from country experiences. BMC Public Health [Internet]. 2017 Apr [cited 2020 Aug 11];17(1):1-12. Available from: https://doi.org/10.1186/s12889-017-4216-9.

17. Alotaibi B, Yassin Y, Mushi A, Maashi F, Thomas A, Mohamed G, et al. Tuberculosis knowledge, attitude and practice among healthcare workers during the 2016 Hajj. PLoS One [Internet]. 2019 Jan [cited 2020 Aug 11];14(1):1-15. Available from: https://doi.org/10.1371/journal.pone.021091 3.

18. Muhammad M, Fadli F. Analisis Faktor Penyebab Multi-Drug Resistance (MDR) Pada Penderita Tuberkulosis. Jurnal Publikasi Kesehatan Masyarakat Indonesia [Internet]. 2019 Aug [cited 2020 Aug 11];6(2):62-7. Available from: http://dx.doi.org/10.20527/jpkmi.v6i2.7454.

19. Devi AU, Cahyo K, Shaluhiyah Z. FaktorFaktor Yang Berhubungan Dengan Perilaku Pasien TB MDR Dalam Pencegahan Penularan TB MDR Di Wilayah Kerja Puskesmas Kota Semarang. Jurnal Kesehatan Masyarakat [Internet]. 2019 Jan [cited 2020 Aug 11];7(1):442-52. Available from: https://ejournal3.undip.ac.id/index.php/jkm/ article/viewFile/23066/21080.

20. Janan M. Faktor-faktor Risiko yang Berhubungan dengan Peningkatan Prevalensi Kejadian TB MDR di Kabupaten Brebes Tahun 2011-2017. Jurnal Kebijakan Kesehatan Indonesia: JKKI [Internet]. 2019 Jun [cited 2020 Aug 11];8(2):64-70. Available from: https://doi.org/10.22146/jkki.36833.

21. Ardiansyah DN, Suryawati C, Adi MS. Provision of Resources in the Implementation of Tuberculosis-Multi Drugs Resistance Treatment Service in "X" 
Hospital. J Medicoeticolegal dan Manaj Rumah Sakit [Internet]. 2019 Dec [cited 2020 Aug 11];8(3):163-9. Available from: https://doi.org/10.18196/jmmr.83103.

22. Parmelia M, Duarsa DP, Sari AK. Faktor yang Berhubungan dengan Kejadian Putus Obat Pada Pasien Tuberkulosis Paru di Puskesma Kota Denpasar. Jurnal Medika Udayana [Internet]. 2019 Sep [cited 2020 Aug 11];8(9):1-6. Available from: https://ojs.unud.ac.id/index.php/eum/article/ download/53069/33015.

23. Purwaningsih E, Trisnantoro L, Kurniawan F. Analisis kebijakan pembiayaan TB di fasilitas kesehatan milik pemerintah era $\mathrm{jkn}$ di kota samarinda. Jurnal Kebijakan Kesehatan Indonesia: JKKI [Internet]. 2018 Jun [cited 2020 Aug 11];07(02):74-8. Available from: https://doi.org/10.22146/jkki.35037.

24. D'Ambrosio L, Bothamley G, Luna JAC, Duarte R, Guglielmetti L, Torrico MM, et al. Team approach to manage difficult-to-treat TB cases: Experiences in Europe and beyond. Pulmonology [Internet]. 2018 Mar [cited 2020 Aug 11];24(2):132-41. Available from: 10.1016/j.rppnen.2017.10.005.

25. Alene KA, Adane AA, Yifiru S, Bitew BD, Adane A, Koye DN. Knowledge and practice of health workers about control and prevention of multidrug-resistant tuberculosis in referral hospitals, Ethiopia: A cross-sectional study. BMJ Open [Internet]. 2019 Feb [cited 2020 Aug 11];9(2):1-8. Available from: https://doi.org/10.1136/bmjopen-2018022948.

26. Yani A, Tasya Z, Syam S. Edukasi Kesehatan Untuk Meningkatkan Pengetahuan Tentang Pengobatan Rutin Pasien TB Paru. MPPKI: Media Publikasi Promosi Kesehat Indonesia [Internet]. 2020 [cited 2020 Aug 11];3(1):74-7. Available from: https://doi/org/10.31934/mppki.v3i1.1032.

27. Espindolaa AL, Varugheseb M, Laskowskic M, Shoukatc A, Heffernand JM, Moghadas SM. Strategies for halting the rise of multidrug resistant TB epidemics: assessing the effect of early case detection and isolation. Int Health [Internet]. $2017 \mathrm{Mar}$ [cited 2020 Aug 11];9(2):80-90. Available from: https://doi.org/10.1093/inthealth/ihw059.
Nardell E. Treatment as prevention and other interventions to reduce transmission of multidrug-resistant tuberculosis. Int J Tuberc Lung Dis. [Internet]. 2019 Apr [cited 2020 Aug 11];23(4):396-404. Available from: https://doi.org/10.5588/ijtld.18.0276.

29. Sayidah D, Sri Rahardjo S, Murti B. Individual and Environmental Risk Factors of Tuberculosis: A New Evidence from Ponorogo, East Java. J Epidemiol Public Heal. [Internet]. 2018 [cited 2020 Aug 11];3(3):353-60. Available from: https://doi.org/10.26911/jepublichealth.2018 .03.03.06.

30. Samal J. Health System and Policy Perspectives of Multidrug-resistant Tuberculosis (TB-MDR) Control in India. J Dev Policy Pract. [Internet]. 2018 Dec [cited 2020 Aug 11];3(1):1-15. Available from: https://doi.org/10.1177/2455133317740448.

31. Akshata JS, Chakrabarthy A. Management of multidrug resistant tuberculosis (TB-MDR) Monitoring is the key to successful outcome. Egypt J Chest Dis Tuberc [Internet]. 2016 Jan [cited 2020 Aug 11];65(2):447-50. Available from: http://dx.doi.org/10.1016/j.ejcdt.2015.12.01 8

32. Reviono R, Harsini H, Aphridasari J, Nugroho IGBI, Damayanti KE. Influence social and healthcare support on psychiatric adverse events in TB-MDR patient. J Infect Dev Ctries. [Internet]. 2018 Jul [cited 2020 Aug 11];12(7):592-6. Available from: https://doi.org/10.3855/jidc.10352.

33. Saifullah S, Mulyadi M, Asniar A. FaktorFaktor Yang Berhubungan Dengan Perilaku Perawatan Kesehatan Tuberkulosis Paru. J Ilmu Keperawatan [Internet]. 2018 [cited 2020 Aug 11];6(1):31-9. Available from: http://jurnal.unsyiah.ac.id/JIK/article/view/1 2269/9503.

34. Widyasrini ER, Probandari AN, Reviono R. Factors Affecting the Success of Multi Drug Resistance (TB-MDR) Tuberculosis Treatment in Residential Surakarta. J Epidemiol Public Heal. [Internet]. 2017 [cited 2020 Aug 11];2(1):45-57. Available from:

https://doi.org/10.26911/jepublichealth.2017 .02.01.05.

28. Nathavitharana RR, Lederer P, Tierney DB, 